\title{
The Effect of the Different Artificial Insemination Time Periods on the Pregnancy Rate of Sapudi Ewes
}

\author{
Cristy Dwi Putri ${ }^{1}$ Ismudiono $^{1^{*}}$, and Emmanuel Djoko Poetranto ${ }^{2}$ \\ ${ }^{l}$ Department of Veterinary Reproduction, Faculty of Veterinary Medicine, Universitas Airlangga, Surabaya-60115, Indonesia \\ ${ }^{2}$ Department of Veterinary Clinic, Faculty of Veterinary Medicine, Universitas Airlangga, Surabaya-60115, Indonesia \\ *Corresponding author's Email: ismudiono@yahoo.co.id ; (DorCiD: 0000-0002-9705-5176
}

\begin{abstract}
Artificial insemination is required to increase the reproduction rate in ruminant breeding. The artificial insemination success rate in sheep only reaches $47.6 \%$, whereas the proposed ideal rate is $70 \%$. One of the factors influencing the artificial insemination success rates in sheep is improper estrus detection, resulting in no fertilization. The present study aimed to determine the effect of different artificial insemination time periods on the pregnancy rates of Sapudi ewes. The research design was based on a completely randomized design. A total of 20 female Sapudi sheep were divided into four treatment groups with five repetitions (for each group). In addition, the observed variables were artificial insemination time in Sapudi ewes. Estrus synchronization in ewes was conducted by injecting PGF $_{2 \alpha}$. The results of the research indicated that ewes subjected to artificial insemination $6,12,18$, and 24 hours after estrus had a pregnancy rate of $20 \%, 100 \%, 60 \%$, and, $60 \%$, respectively. It can be concluded that the time differences in artificial insemination significantly influence the pregnancy rate in Sapudi ewes'.
\end{abstract}

Keywords: Artificial insemination, Estrus, Pregnancy rate, Sapudi ewes

\section{INTRODUCTION}

Sapudi sheep is a family of native Indonesian sheep with the characteristics of a larger tail size than other sheep strains. This different characteristic provides benefits to farmers during the dry season, since Sapudi sheep can reserve energy in their tails (Tanziila, 2018). However, the big size of Sapudi sheep's tails is also one of the problematic factors to conduct natural mating. Therefore, human assistance is required to conduct artificial insemination in order to improve the reproduction rate (Hafez, 2000).

Artificial insemination is a reproductive bio-technique that relies on improving livestock genetic quality, controlling reproductive infectious diseases, and optimizing the reproductive appearance (Ramadhani, 2016). However, the insemination success rate of sheep only reaches $47.6 \%$, whereas the ideal rate is believed to be $70 \%$ (Rizal, 2006). This situation can be affected by many factors, including the quality of the frozen semen which experiences a quality decrease after thawing, incorrect implementation of artificial insemination, and incorrect estrus detection which results in a fertilization failure (Abebe and Alemayehu, 2021). The estrus period detection is highly complicated to perform, which results in difficulties in determining the ovulation period (Miguel-Cruz et al., 2019). The length of ewes' estrus period is around 24-36 hours, and the sheep's ovulation period begins approximately 24-30 hours from the beginning of the estrus time (Miguel-Cruz et al., 2019). Determining the ovulation period is considered important for an exact time for artificial insemination (Ramadhani, 2016).

One of the alternative methods to overcome the problems above is conducting an estrus synchronization. Estrus synchronization is a method to hormonized insemination (insemination at the same time), within a short period of time, so can be estimated in animal models (Mirshamsollahi, 2016). As a result, livestock can be inseminated at the same time. The estrus synchronization commonly is achieved using prostaglandin F2 $\alpha$ or $\mathrm{PGF}_{2 \alpha}$ hormone (Mirshamsollahi, 2016; Miguel-Cruz et al., 2019). The hormone acts by lysing the corpus luteum, which leads to a decreased level of the progesterone hormone (Ferrag et al., 2017). The low progesterone is followed by an FSH increase, which stimulates the development of matured follicles causing the heat in sheep (Stenbak et al., 2001). The $\mathrm{PGF}_{2 \alpha}$ hormones can only regress the active corpus luteum rather than starting or growing corpus luteum (Sudarmaji et al., 2004). The implementation of massive estrus synchronization will improve the reproductive efficiency of the livestock, optimize the artificial insemination implementation, and increase the group fertility (Sardi, 2011).

Pregnancy failure often occurs due to an inappropriate estrus detection, which results in incorrect artificial insemination time (Sigit et al., 2014). Based on the background above, the present study was done for determining the effects of insemination time on the pregnancy rate of Sapudi ewes. 


\section{MATERIAL AND METHODS}

The research design in this study was a completely randomized design. The current study was conducted at Dinas Peternakan Provinsi Jawa Timur, Garahan, Jember from April to June 2017.

\section{Ethical approval}

All processes and experiments of the present study (in vivo and in vitro) were approved by the ethical committee of Universitas Airlangga.

\section{Estrus detection and synchronization}

This research comprised of 20 unfertilized Sapudi ewes, which were examined with Ultrasound guided (USG) device. Estrus detection was done using USG according to the method of Macías et al. (2017). The estrus synchronization is achieved by intramuscular administration of prostaglandin F2 $\alpha$ or PGF2 $\alpha$ at the dose of $7.5 \mathrm{mg} / \mathrm{sheep}$. In addition, the PGF2 $\alpha$ injection in the current study was carried out twice to obtain simultaneous sheep estrus with an interval of 11 days. The sheep would be sexually excited two days after PGF $_{2 \alpha}$ injection (Srianto et al., 2010).

\section{Artificial insemination}

The artificial insemination was carried out by employing the frozen semen of Sapudi sheep obtained from Farm animal Institute, Universitas Airlangga of Indonesia. In addition, this research utilized $0.25 \mathrm{ml}$ of mini straws with the concentration of each straw $\pm 50 \times 106$ spermatozoa (Hardijanto et al., 2010). The number of straws was adjusted to the required spermatozoa concentration for artificial insemination on the ewes. Afterward, the straw was thawed on the water at room temperature for 30 seconds, and then it was inserted into the artificial insemination gun. Next, the straw tip was cut using a pair of scissors. After that, the plastic sheath was installed on an artificial insemination gun, which already contained the straw (Hardijanto et al., 2010).

The 20 ewe samples were divided into four groups. The artificial insemination in the first group was carried out 6 hours after the estrus occurred (P1). Meanwhile, artificial insemination in the second group was conducted 12 hours after the estrus was detected (P2). The artificial insemination of the third group was performed 18 hours after the sheep were in estrus (P3). Finally, the artificial insemination in the fourth group was carried out 24 hours after the estrus signs appeared (P4). Furthermore, the semen was sprayed in the area before the uterine cornua branch with a sperm concentration of approximately $\pm 50 \times 10^{6}$ on each spraying (Satiti et al., 2014). The ewes' pregnancy diagnosis was conducted when the pregnancy reached 60 days by employing Carelife portable USG device.

\section{Data analysis}

The research data were the pregnancy rate analyzed by using F-test or One-way Factorial ANOVA, and followed by Duncan's Multiple Range Test if there were differences in the ANOVA Factorial test $(\mathrm{p}<0.05)$.

\section{RESULTS}

The pregnancy diagnosis of the examined Sapudi ewes was performed using a USG device with different artificial insemination times generated the pregnancy rate (Table 1). The results identified there was a significant difference between P1, where the artificial Insemination was conducted 6 hours after the initial estrus, and P2, where the artificial Insemination was administered 12 hours after the initial estrus, on the pregnancy success rate. On the other hand, the results obtained from P2, and from P3 where the artificial insemination was performed 18 hours after the initial estrus, were not significantly different in affecting the pregnancy success rate. Similarly, the results achieved from the P2 group and the P4 group where the artificial insemination was carried out 24 hours after the initial estrus, were not significantly different regarding the pregnancy success rate. As can be seen in Table 1, Sapudi ewes in P1 exhibited a pregnancy rate of $20 \%$. Meanwhile, the ewes in P2 were fertilized $100 \%$ after being inseminated artificially 12 hours after the estrus. The artificial insemination conducted in Sapudi sheep 18 hours after the estrus (P3) resulted in the pregnancy rate of $60 \%$. In addition, the pregnancy rates of the ewes artificially inseminated 24 hours after estrus (P4) amounted to $60 \%$.

Table 1. Pregnancy Rates of Sapudi Ewes' with different artificial insemination times

\begin{tabular}{lcc}
\hline Group & Repetition & Pregnancy Rate (\%) \\
\hline P1 & 5 & $(20 \%)^{\mathrm{a}}$ \\
P2 & 5 & $(100 \%)^{\mathrm{b}}$ \\
P3 & 5 & $(60 \%)^{\mathrm{ab}}$ \\
P4 & 5 & $(60 \%)^{\mathrm{ab}}$ \\
\hline
\end{tabular}

P1: Artificial Insemination was conducted 6 hours after estrus, P2: Artificial Insemination was conducted 12 hours after estrus, P3: Artificial Insemination was conducted 18 hours after estrus, P4: Artificial Insemination was conducted 24 hours after estrus 


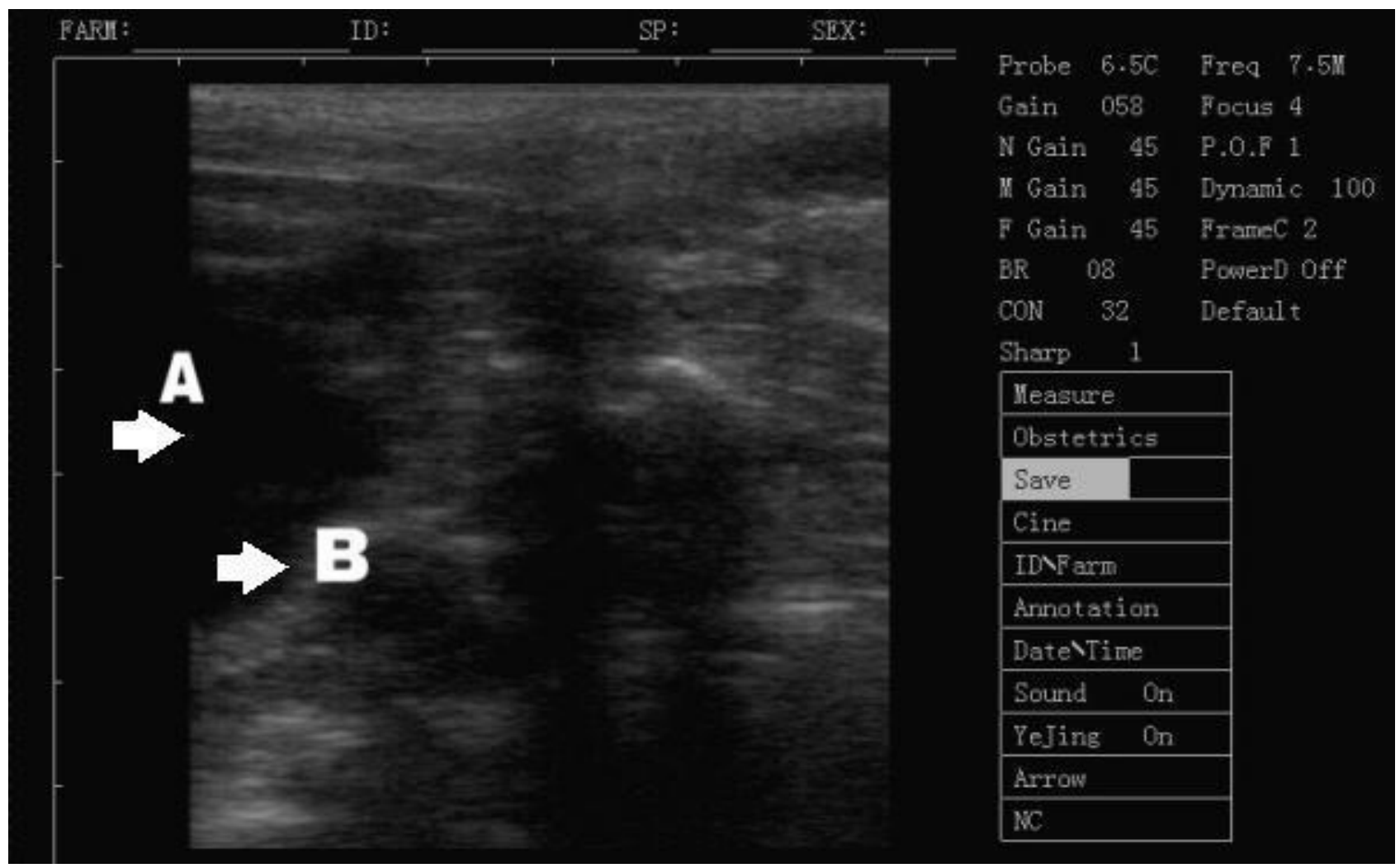

Figure 1. The result of Ultrasound-guided examination on Sapudi ewes 60 days after artificial insemination. A: Amniotic fluid is black, B: The fetus appears white in amniotic fluid

\section{DISCUSSION}

Findings demonstrated that the highest pregnancy rate appeared if the artificial insemination was carried out 12 hours (P2) after the estrus was detected. The results of pregnancy diagnosis employing USG device in Sapudi sheep is illustrated in Figure 1.

The $\mathrm{PGF}_{2 \alpha}$ Injection was carried out on day 1 and day 11 with the same dose, according to Toelihere (1981), stating that PGF2 $\alpha$ injection can be performed with one injection or two injections with an interval of 11-12 days. The PGF2 $\alpha$ injection can lyse the corpus luteum, causing a follicular period process. It causes estrus and ovulation symptoms on the ewes. The ewes will be in estrus one to three days after the hormone treatment was administered (Martinez-Ros et al., 2018). Ewes indicate the signs of estrus if they keep bleating frequently, and it can be identified through the physical condition where transparent mucus comes from their genital organs, the vulva looks swollen, and the vulvar mucosa appears purplish-red and warm when touched. Moreover, if they are grouped with other ewes, they indicate standing heat (Martinez-Ros et al., 2018).

The high pregnancy success rate can be influenced by controlled estrus and the insemination time. The number of ovulatory follicles increases estrogen levels in serum, and this condition can prolong the estrus (Setiatin, 2015; MartinezRos et al., 2018). Estrus synchronization in ewes is carried out by injecting PGF2 $\alpha$, which can lyse the corpus luteum, and cause a follicular period. These factors cause estrus and ovulation symptoms of the ewes. One to three days after being administered with hormonal treatment, the ewes will be in estrus (Martinez-Ros et al., 2018).

The artificial insemination conducted 12 hours after the initial estrus signs resulted in a higher pregnancy rate, compared to the other treatments (Table 1). It implies that the proper artificial insemination timing is 12 hours after the initial estrus signs are detected (Srianto et al., 2010). The ewes' estrus period is around 24-36 hours, and the ovulation period begins approximately 24-30 hours after the estrus (Srianto et al., 2010). The artificial insemination in the other treatments identified imperfect pregnancy results because, in the first treatment, where artificial insemination was conducted 6 hours after estrus, the fusion between spermatozoa and egg cells was too early. The spermatozoa cells can only survive in the female genital tract for 12-24 hours, while ovulation occurs 24- 30 hours after the initial estrus signs appear (Table 1). Hence, fertilization cannot occur. At the third treatment where the artificial insemination was conducted 18 hours after estrus, and the fourth treatment where the artificial insemination was conducted 24 hours after estrus, the pregnancy rate was lower. It occurred because the spermatozoa cells stayed in the female genital tract for 30 hours with a capacitation period of 1.5 hours in the oviduct (Bedford, 1970). Moreover, ovulation happens 24 hours after the initial estrus sign; therefore, the possibility of fertilization is not strong.

The samples of the experiment were limited to 20 ewes of productive age so that the expected value obtained was less than or equal to five $(\leq 5)$. This fact might be caused by the feed given, the estrus time, the estrus period, and the 
individual response of the Sapudi ewes to each different treatment. Each animal may respond differently to the treatment provided due to the livestock conditions and feed given (Toelihere, 1981; Thornton, 2010).

\section{CONCLUSION}

The difference in artificial insemination time influenced Sapudi sheep pregnancy rate. The highest pregnancy rate was obtained in the second treatment, namely Sapudi sheep, received artificial insemination 12 hours after estrus signs appeared. Therefore, the best time to carry out artificial insemination seems to be 12 hours after the estrus signs were detected.

\section{DECLARATION}

\section{Author's contribution}

All authors had equal roles in conducting, writing, and editing the manuscript.

\section{Competing interests}

The author did not report any conflicts of interest in the current research.

\section{Ethical considerations}

Ethical issues (including plagiarism, consent to publish, misconduct, data fabrication and/or falsification, double publication and/or submission, and redundancy) have been checked by the authors.

\section{REFERENCES}

Abebe B, and Alemayehu M (2021). Challenges and Opportunities on Estrus Synchronization and Mass Artificial Insemination in Dairy Cows for Smallholders in Ethiopia. International Journal of Zoology, Article ID: 9914095. DOI: https://doi.org/10.1155/2021/9914095

Bedford JM (1970). The saga of mammalian sperm from ejaculation to syngamy. In: Mammalian reproduction. Springer, Berlin, Heidelberg, pp. 124-82. DOI: https://www.doi.org/10.1007/978-3-642-64993-6_10

Farrag B, El-Hawy AS, and El-Bassiony MF (2017). Improving Reproductive and Productive Efficiency of Barki Sheep by using $\mathrm{GnRH}$ and Selenium. World Veterinary Journal, 7(4): 128-136. Available at: http://wvj.scienceline.com/attachments/article/48/WVJ\%207(4)\%20128-136,\%20Dec\%2025,\%202017.pdf

Hafez ESE (2000). Reproduction in Farm Animals. 7th Ed. Lippincott Williams and Wilkins, A Wolters Kluwer Company, Philadelphia. pp. 451-470. Available at: https://www.wiley.com/en-us/Reproduction+in+Farm+Animals\%2C+7th+Edition-p$\underline{9781118710289}$

Hardijanto SS, Sardjito T, Hernawati T, and Suprayogi TW (2010). Inseminasi Buatan [Artificial insemination]. Fakultas Kedokteran Hewan. Airlangga University Press. Surabaya. Availble https://sinta.ristekbrin.go.id/authors/detail?id=6055753\&view=documentsgs

Martinez-Ros P, Rios-Abellan A, and Gonzalez-Bulnes A (2018). Influence of Progesterone-Treatment Length and eCG Administration on Appearance of Estrus Behavior, Ovulatory Success and Fertility in Sheep. Animals (Basel), 9(1): 9. DOI: https://dx.doi.org/10.3390\%2Fani9010009

Macías A, Ferrer LM, Ramos JJ, Lidón I, Rebollar R, Lacasta D, and Tejedor MT (2017). Technical Note: A new device for cervical insemination of sheep - design and field test. Journal of Animal Science, 95(12): 5263-5269. DOI: https://www.doi.org/10.2527/jas2017.1951

Miguel-Cruz E, Mejía-Villanueva O, and Zarco L (2019). Induction of fertile estrus without the use of steroid hormones in seasonally anestrous Suffolk ewes. Animal Bioscience, 32(11): 1673-1685. DOI: https://www.doi.org/10.5713/ajas.18.0769

Mirshamsollahi A (2016). Comparison of different methods of oestrus synchronization on reproductive performance of farahani sheep in Iran. Iranian Journal of Applied Animal Science, 6(4): 849-853. Available at: http://ijas.iaurasht.ac.ir/article_526630.html

Ramadhani AZS (2016). Status reproduksi dan potensi populasi berbagai bangsa sapi di desa karang endah kecamatan terbanggi besar kabupaten lampung tengah [Reproductive status and population potential of various breeds of cattle in Karang Endah Village, Sub-District of Teranggi Besar, Central Lampung Regency]. Jurnal Ilmiah Peternakan Terpadu, 4(1): 55-62. DOI: http://dx.doi.org/10.23960/jipt.v4i1.p\%25p

Rizal M (2006). Fertility of Frozen-Thawed Semen From Ejaculation and Frozen-Thawed Spermatozoa From Cauda Epididymis of Garut Rams. Jurnal Sain Veteriner, 24: 49-57. Available at: https://jurnal.ugm.ac.id/jsv/article/view/347/236

Sardi M (2011). Respon estrus kerbau lumpur terhadap injeksi pgf2 $\alpha$ di kecamatan bangkinang seberang kabupaten kampar. Universitas Islam Negeri Sultan Sarif Kasim Riau, Indonesia. Available at: http://repository.uin-suska.ac.id/2227/

Satiti D, Triana IN, and Rahardjo AP (2014). Pengaruh Penggunaan Kombinasi Progesteron (Medroxy Progesterone Acetate) dan Prostaglandin (PGF2 $\alpha$ ) Injeksi Terhadap Persentase Birahi dan Kebuntingan pada Domba Ekor Gemuk [Effect of Using a Combination of Progesterone (Medroxy Progesterone Acetate) and Prostaglandin (PGF2 $\alpha$ ) Injection on the Percentage of Erection and Pregnancy in Fat Tailed Sheep]. Veterinaria, 7(2): 23-33. Available at: http://repository.unair.ac.id/21487/

Setiatin ET (2015). Pemanfaatan Ekstrak Hipotalamus Kambing Sebagai Upaya Optimalisasi Kesuburan Kambing Kejobong Betina (the use of goat hypothalamic extract to optimalize fertility of female kejobong goats). Jurnal Veteriner, 16(3): 343-350. 
Available at: https://ojs.unud.ac.id/index.php/jvet/article/view/16248

Sigit S, Lamid M, and Hermadi HA (2014). Production of progesterone implants to mass estrus synchronization and optimization levels pregnancy on fat-tailed sheep of strains sapudi Madura Island. International Journal of Academic Research, 6(6): 235-238. Available at: http://repository.unair.ac.id/63532/13/Abstrak\%20016.pdf

Srianto P, Anwar H, Pantja S, Samik A, and Safitri E (2010). Buku Ajar Fisiologi Reproduksi pada Ternak. Airlangga University Press, Airlangga. Available at: https://ditjenpkh.pertanian.go.id/perpustakaan/pusvetma/index.php?p=show_detail\&id=2356

Stenbak TK, Redmer DA, Berginsk HR, Erickson AS, Navanukraw C, Toutges MJ, and Grazul-Bilska AT (2001). Effects of follicle stimulating hormone (FSH) on follicular development, oocyte retrieval, and in vitro fertilization (IVF) in ewes during breeding season and seasonal anestrus. Theriogenology, 56(1): 51-64. DOI: https://doi.org/10.1016/S0093-691X(01)00542-8

Sudarmaji S, Malik ABD, and Gunawan AAM (2004). Pengaruh Penyuntikan Prostaglandin terhadap Persentase Birahi dan Angka Kebuntingan Sapi Bali dan PO di Kalimantan Selatan [The Effect of Prostaglandin Injection on Percentage of Erection and Pregnancy Rates for Bali and PO Cattle in South Kalimantan]. Majalah Ilmiah Peternakan, 10: 1-10. Available at: https://ojs.unud.ac.id/index.php/mip/article/view/1751

Tanziila M (2018). Karakteristik Sifat Kualitatif Dan Kuantitatif Domba Sapudi H. Universitas Brawijaya, Indonesia. Available at: http://repository.ub.ac.id/13599/

Thornton PK (2010). Livestock production: recent trends, future prospects. Philosophical transactions of the Royal Society of London. Series B, Biological sciences, 365(1554): 2853-2867. DOI: https://www.doi.org/10.1098/rstb.2010.0134

Toelihere MR (1981). Fisiologi Reproduksi pada Ternak [Reproductive Physiology in Livestock]. Angkasa, Bandung, Indonesia. Available at: http://library.um.ac.id/free-contents/index.php/buku/detail/fisiologi-reproduksi-pada-ternak-mozes-r-toelihere$\underline{1857 . h t m l}$ 